\title{
Anatomical Variations of the Anterior Belly of the Digastric Muscle
}

\author{
Variaciones Anatómicas del Vientre Anterior del Músculo Digástrico
}

\author{
Khayelihle Guambe; Brenda Z. De Gama; Pamela Pillay \& Kapil S. Satyapal
}

GUAMBE, K.; DE GAMA, B. Z.; PILlAY, P. \& SATYAPAL, K. S. Anatomical variations of the anterior belly of the digastric muscle. Int. J. Morphol., 37(4):1504-1508, 2019.

SUMMARY: A routine dissection of the digastric muscle reflected that it originated by two muscle bellies namely. the anterior and posterior belly which are connected by an intermediate tendon (IT). These bellies originated from the mastoid process of the temporal bone and the digastric fossa of the mandible respectively. The digastric muscle serves as an important surgical landmark in surgical interventions involving the submental area however, accessory bellies may interfere with surgical intervention in this area. Therefore, this study aimed to document the occurrence of the anatomical variations in the anterior belly of the digastric muscle (ABDM) in a selected number of cadaveric samples. Ten bilateral adult cadaveric head and neck specimens $(n=20)$ were macro-dissected in order to document the morphology of the digastric muscle. The accessory bellies in the ABDM was observed in $60 \%$ of the specimens. Unilateral and bilateral variations were observed in $20 \%$ and $30 \%$ of the specimens, respectively. These accessory bellies originated in the digastric fossa, ABDM, IT and hyoid bone, and inserted into the mylohyoid raphe, mylohyoid muscle and hyoid bone. In addition, an anomalous main ABDM was observed in $10 \%$ of the specimens inserting through a transverse tendon into the hyoid bone. Variations in the digastric muscle are common especially the accessory bellies, therefore, a comprehensive understanding of these anatomical variations could be of clinical importance to the surgeons during head and neck radiological diagnosis and surgical interventions.

KEY WORDS: Digastric muscle; Anterior belly; Accessory belly; Anatomical variation.

\section{INTRODUCTION}

The digastric muscle originates as dual bellies; an anterior and posterior belly, from the inferior base of the cranium and the inferior margin of the mandible, hence called the 'digastric'. The intermediate tendon (IT) unites these muscle bellies and curved at an angle above the hyoid bone and inserts into this bone by fascia (Harrison et al., 2009). The ABDM originates from the digastric fossa of the mandible, while the posterior belly of the digastric muscle (PBDM) originated from the mastoid notch of the temporal bone (Harrison et al.; Moore et al., 2014). Morphologic variations in the digastric muscle have been linked with the anomalous arches during its development.

As a result, the morphologic variation in the digastric musculature includes the presence of an accessory belly in the ABDM and has been the commonly documented in the literature reviewed, with various authors describing different forms, shapes and attachments of this variant muscle. Firstly, the accessory belly may originate either from the mandible, mylohyoid muscle, IT, digastric fossa, and the main ante- rior or opposite anterior belly (Rani et al. 2013; Quadros et al., 2013; Azedero et al., 2015). Secondly, it may insert into the midline raphe of the mylohyoid muscle, the IT, the mandible and contralateral ABDM (Aktekin et al., 2003; Reyes et al., 2007; Rani et al.). Lastly, the accessory belly may vary in its course and travel either ipsilaterally on the same side of its origin from the mandible or contralaterally crossing the mandible from its point of origin (Liquidate et al., 2007; Kyung et al., 2011; Azeredo et al., 2016).

With its pivotal role in a variety of surgical procedures involving the submental region such as submental artery flaps, rejuvenation, submental rhytidectomy and lipectomy (Zdilla et al., 2016). Knowledge of the anatomy of the digastric muscle and its variations is of importance, especially when the accessory belly could be easily misinterpreted during radiographic imaging of the submental region. Therefore, this study is aimed to document the anatomic variations of the ABDM in a selected number of adult cadaveric specimens. 


\section{MATERIAL AND METHOD}

Macro-dissection of the digastric muscles was conducted bilaterally on 10 adult cadaveric head and neck specimens $(n=20)$. The sample size consisted of 8 males and 2 females between the age range of $33-$ 84 years old, which were obtained from the Department of Clinical Anatomy, School of Laboratory Medicine and Medical Sciences, College of Health Sciences, University of KwaZulu-Natal, South Africa. Ethical clearance was obtained from the University Biomedical Research Ethics Committee (BE530/17). The skin and subcutaneous fascia overlying the anterior aspect of the neck was removed. The overlying platysma and sternocleidomastoid muscles were dissected and gently retracted superiorly exposing the underlying digastric muscles. The origin, course and insertion of the digastric muscles were documented according to Zhao et al. (2015) classification method and digital photographs of the digastric musculature were taken using a camera (Canon PowerShot SX50 HS, 12.1 Megapixel), for morphological analysis.

\section{RESULTS}

Morphological Analysis of the Digastric Muscles. In $40 \%$ (4/10) of the specimens, the typical origin and insertion of the digastric muscle was observed. While, the remainder $(60 \% ; 6 / 10)$ showed a morphological variance in the accessory bellies. The accessory bellies documented were both unilateral and bilateral. These bellies arose from the digastric fossa, the IT, the medial margin of the main ABDM, the mandible and hyoid bone.

i.The main anterior bellies of the digastric muscle had a typical origin from the mandible as described in the standard anatomical literature, however, it had an abnormal insertion onto the hyoid bone via a transverse tendon situated above the hyoid bone. The medial portions of these bellies were continuous distally (Fig. 1).

ii. Unilateral left accessory belly originated via a narrow tendon from the inferior margin of the mandible and coursed superficially on the left ABDM, and its fibers were inserted into the hyoid bone (Fig. 2).

iii. A Type I (unilateral) triangulated left accessory belly originated from left ABDM posteriorly and inserted into the midline of the mylohyoid raphe (Fig. 3).

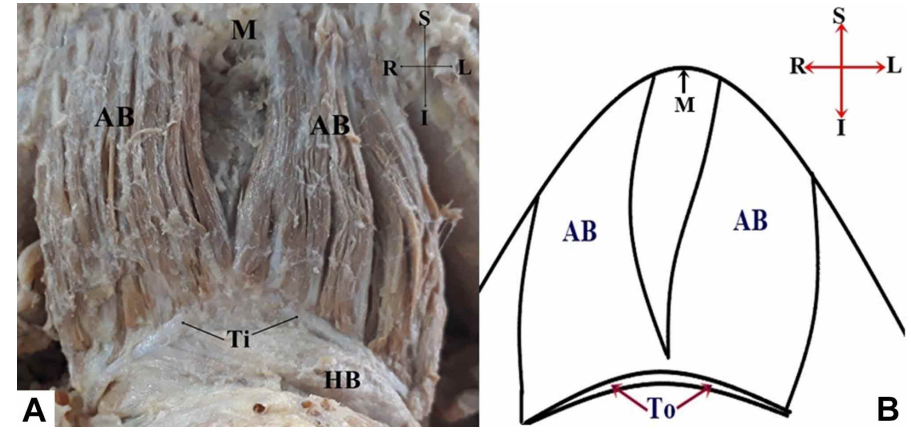

Fig.1. The photograph (A) and associated illustration (B) showing a varying main ABDM. AB. Anterior belly of the digastric muscles; HB. Hyoid bone; M. Mandible; Ti. Tendinous Insertion.

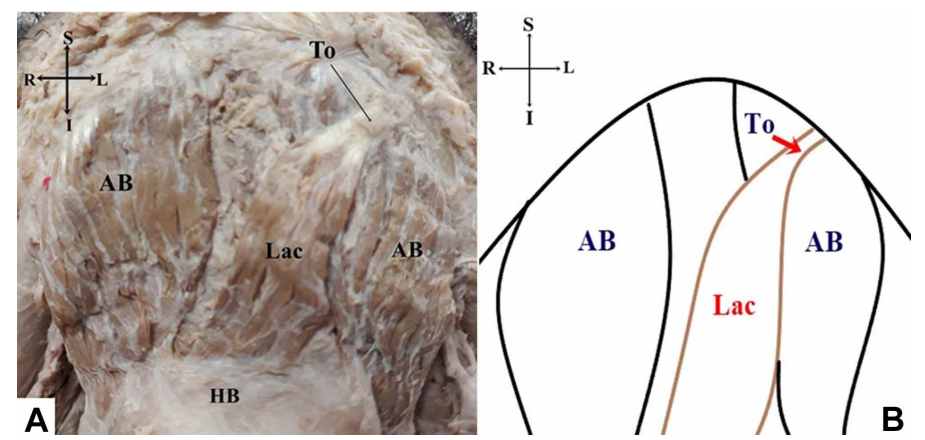

Fig. 2. A. The photograph and B associated illustration showing the oblique left-sided accessory belly of the ABDM. AB.Anterior belly of the digastric muscles; HB. Hyoid bone; Lac. Left Accessory belly; To. Tendinous origin.

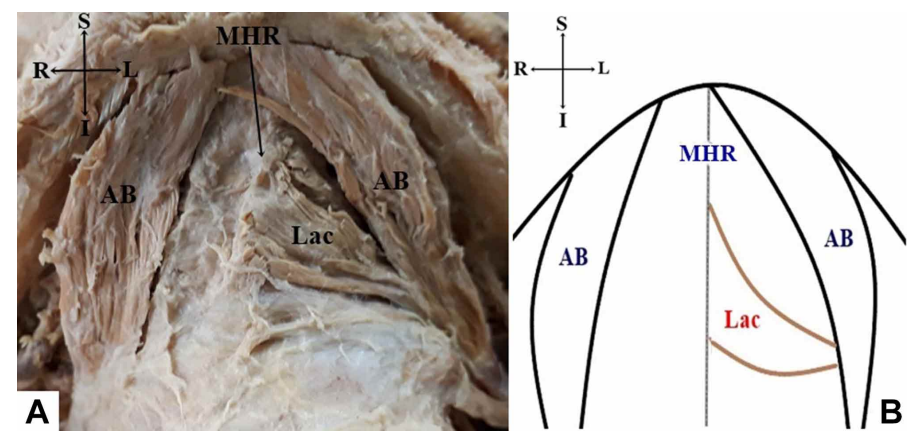

Fig. 3: The photograph (A) and associated illustration (B) showing a left-sided accessory belly of the ABDM. AB. Anterior belly of the digastric muscles; Lac. Left Accessory belly; MHR. Mylohyoid raphe.

iv. A Type II bilateral accessory belly; right and left belly arranged in a triangle. This muscle originated with the vertex in the IT inferiorly and inserted via a base onto the midline of the mylohyoid raphe of the mylohyoid muscle (Fig. 4).

v. The upper and lower muscle fibers crossed centrally into opposite directions, the upper muscle fibers originated from the digastric fossa superficial to the left main ABDM descended inferiorly and inserted onto the medial margin of the right ABDM. On the right side, the lower muscle fibers originated from the 
body of the hyoid bone and ascended transversely to insert into the medial margin of the left ABDM. (Fig. 5).

vi. Bilateral accessory bellies, the right and left belly originated from the respective main ABDM distally. Centrally, the anterior muscle slips originated from the internal surface of the internal surface of the mental symphysis (Fig. 6).

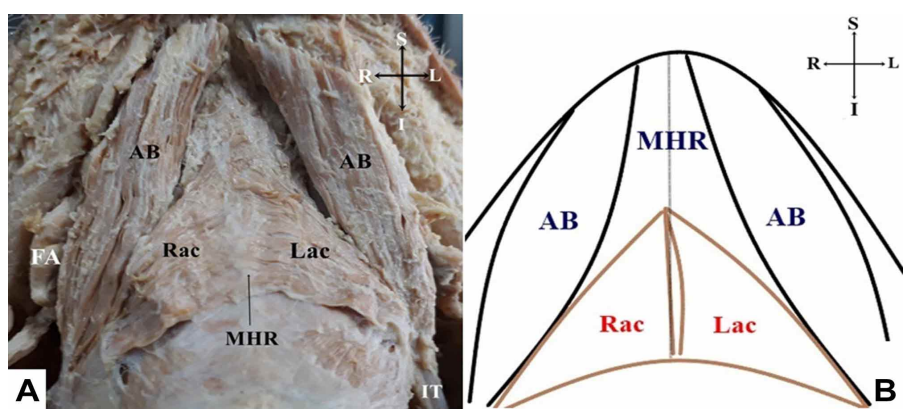

Fig. 4. The photograph (A) and associated illustration (B) showing the triangulated accessory bellies of the ABDM on both sides. AB. Anterior belly of the digastric muscles; FA. Facial artery; IT. Intermediate tendon; Lac. Left Accessory belly; MHR. Mylohyoid raphe; Rac. Rigth accesory belly.

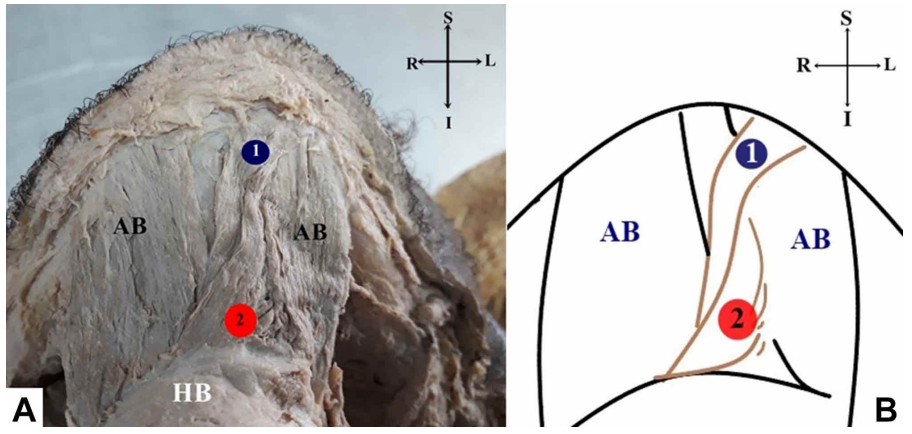

Fig. 5. The photograph (A) and associated illustration (B) showing the opposite pair of accessory bellies of the ABDM. AB. Anterior belly of the digastric muscles; HB. Hyoid bone; 1 . Upper accessory belly; 2. Lower accessory belly.
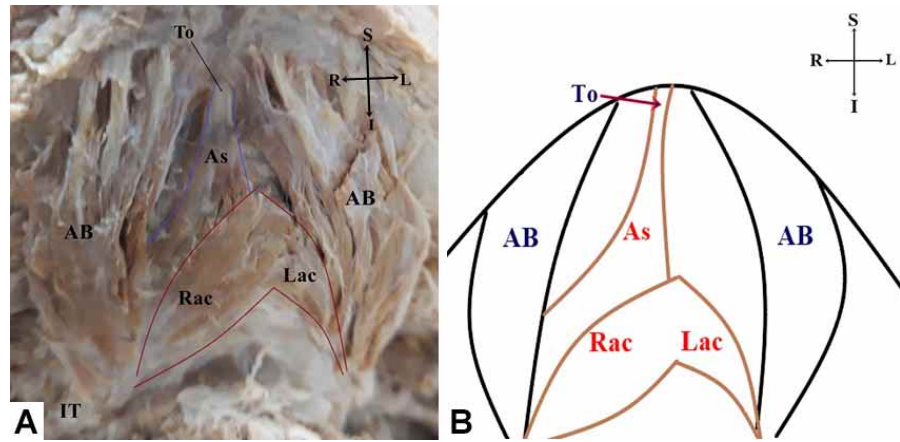

Fig. 6. The photograph (A) and associated illustration (B) showing the triple accessory bellies of the ABDM (namely, the anterior muscle slip, right and left belly). AB. Anterior belly of the digastric muscles; As. Anterior muscle slip; Lac. Left Accessory belly; Rac. Rigth accesory belly; To. Tendinous origin.

\section{DISCUSSION}

The morphological variations in the digastric muscle are common and are extensively reported in the anatomical literature, in particular, regarding the presence of the accessory belly of the ABDM. Abnormalities in the pharyngeal arches from which the digastric muscle is derived are claimed to contribute to the formation of these variations. For instance, anomalies in the neural crest cells of the 1st pharyngeal arch may cause the development of an accessory belly (Mascaro et al., 2011; Chaithra Rao et al., 2016). While, a deficiency during differentiation of the mesodermal cells may either result in a unilateral or bilateral accessory belly (Chaithra Rao et al.). As a result, bilateral accessory bellies have been frequently documented in literature (Aktekin et al.; Liquidate et al.; Mascaro et al.; Kyung et al.; Chaithra Rao et al.) and the majority of these are asymmetrical (Rani et al.; Buffoli et al., 2016; Accioly Lins et al., 2017). This study documented both unilateral and bilateral accessory belly variations.

Different anatomical descriptions and classifications suggested by various authors have reported these anatomical variations according to their origin, composition, course and location (Ozgur et al., 2007; Zhao et al., 2015). These accessory bellies originated in the digastric fossa of the mandible, the IT, the main ABDM and the hyoid bone; and may insert into the IT, the midline of the mylohyoid raphe, the hyoid bone and the mandible (Mascaro et al.; Quadros et al.; Rani et al.). Aktekin et al. reported a bilateral accessory belly originating from the IT crossing the midline to form an ' $\mathrm{X}$ shape'. A similar pattern was observed by Mascaro et al., but the accessory bellies did not cross the midline. While a digastric muscle with three accessory bellies has also been reported (Kyung et al.; Nayak et al., 2017).

Reyes et al. reported a triangular shaped accessory belly that originated bilaterally from the IT and inserted into the midline of the mylohyoid raphe. A similar observation was documented in this study, unilaterally and bilaterally. A bilateral variation of the ABDM were described having three accessory bellies namely, the right, left and posterior or lower posterior accessory belly originated from either side of the digastric fossa of the mandible and IT, respectively (Kyung et al.; Raju et al., 2014). Turan-Ozdemir et al. (2004) described similar bilateral accessory bellies, however these accessory bellies originated from either 
sides of the IT and the digastric fossa. Likewise, the bilateral accessory bellies documented in this study corroborated with the afore-mentioned findings documented by TuranOzdemir et al. This study further documented a unilateral oblique belly that originated through a tendon from the inferior margin of the mandible and travelled superficial to the ABDM and inserted distally on both right and left halves of the hyoid bone. On the other hand, an anomalous main ABDM inserted into the hyoid bone via a transverse tendon.

The digastric muscle is involved in deglutition and mastication by elevating the hyoid bone and depressing the mandible, respectively. Thus, anatomical variations in the digastric muscle may possibly alter these functions and may cause imbalance in the musculature of the anterior region of the neck, larynx and floor of the mouth especially in cases where variations occur unilaterally (Mascaro et al.). Furthermore, excess tissue in the suprahyoid region may be misinterpreted as lymph nodes, tumor or metastases during radiological diagnosis (Mascaro et al.; Reyes et al.; Chaithra Rao et al.; Accioly Lins et al.).

\section{CONCLUSION}

This study provides a brief overview of a prevalence of the accessory belly of the ABDM in a selected adult population sample size. The results revealed varying formations of the accessory belly occurring either unilateral or bilateral. Therefore, these findings may be of significance to the anatomists and contributes into the knowledge of the morphological variations that exists in the digastric muscle.

\section{ACKNOWLEDGEMENTS}

The authors would like to extend their gratitude to the University of KwaZulu Natal, College of Health Sciences and National Research Foundation (NRF) for funding this project, to Dr. Wilbert Sibanda for his assistance with statistical analysis and also to the technical staff (Mr. Celumusa Mbokazi, Mr. Prakash Mohanlal) from the Department of Clinical Anatomy for their skillful technical assistance.

GUAMBE, K.; DE GAMA, B. Z.; PILLAY, P. \& SATYAPAL, K. S. Variaciones anatómicas del vientre anterior del músculo digástrico. Int. J. Morphol., 37(4):1504-1508, 2019.

RESUMEN: Una disección de rutina del músculo digástrico refleja que se éste originaba por dos vientres musculares, anterior y posterior conectados por un tendón intermedio (IT).
Estos vientres se originaban a partir del proceso mastoide del hueso temporal y de la fosa digástrica de la mandíbula, respectivamente. El músculo digástrico sirve como un hito quirúrgico importante en las intervenciones que involucran el área submental. Sin embargo, los vientres accesorios pueden obstaculizar la intervención quirúrgica en esta área. Por lo anterior, este estudio tuvo como objetivo documentar observaciones de las variaciones anatómicas en el vientre anterior del músculo digástrico (VAMD) en un número seleccionado de cadáveres. Las muestras consistieron en 10 cabezas y cuellos cadavéricos de individuos adultos, estudiadas bilateralmente $(n=20)$. Estas muestras fueron disecadas para documentar la morfología del músculo digástrico. Los vientres accesorios en el VAMD se observaron en el $60 \%$ de los casos. Se observaron variaciones unilaterales y bilaterales en el $20 \%$ y el $30 \%$ de las muestras, respectivamente. Estos vientres accesorios se originaban en la fosa digástrica, VAMD, IT y hueso hioides, y se insertaban en el rafe milohioideo, el músculo milohioideo y el hueso hioides. Además, se observó un VAMD principal anómalo en el $10 \%$ de las muestras que se insertaban a través de un tendón transversal en el hueso hioides. Las variaciones en el músculo digástrico son comunes, especialmente los vientres accesorios, por lo tanto, un conocimiento completo de estas variaciones anatómicas podría ser de importancia clínica durante el diagnóstico radiológico de cabeza y cuello y en las intervenciones quirúrgicas de la región.

PALABRAS CLAVE: Músculo digástrico; Vientre anterior; Vientre accesorio; Variación anatómica.

\section{REFERENCES}

Accioly Lins, C. C. S.; Corrêa, D. I. M.; Lima, R. S.; da Silva, C. C.; Villarouco, F. M. O.; da Silva, N. A. \& Bezerra, A. J. Anatomical study and variation of the anterior belly of digastric muscle: case report. $M O J$ Anat. Physiol., 3(4):118-20, 2017.

Aktekin, M.; Kurtoglu, Z. \& Oztürk, A. H. A bilateral and symmetrical variation of the anterior belly of the digastric muscle. Acta Med. Okayama, 57(4):205-7, 2003.

Azeredo, R. A.; Cesconetto, L. A. \& Torres, L. H. S. Bilateral variation of the anterior belly of digastric muscle. J. Morphol. Sci., 33(4):215-7, 2016.

Buffoli, B.; Lancini, D.; Ferrari, M.; Belotti, F.; Nicolai, P.; Tschabitscher, M.; Rezzani, R. \& Rodella, L. F. Symmetrical anatomical variant of the anterior belly of the digastric muscle: clinical implicat. Folia Morphol. (Warsz), 75(1):112-6, 2016.

Chaithra Rao, B. R.; Sreepadma, S.; Kulkarni, V. \& Deshpande, S. K. Anatomical variation of digastric muscle and its clinical implications. Int. J. Anat. Res., 4(3):2882-5, 2016.

Harrison, L. B.; Sessions, R. B. \& Hong, W. K. Head and Neck Cancer: A Multidisciplinary Approach. New York, Lippincott Williams \& Wilkins, 2009.

Kyung, D. S.; Lee, J. H.; Lee, Y. P.; Kim, D. K. \& Choi, I. J. Bilateral variations of the head of the digastric muscle in Korean: a case report. Anat. Cell Biol., 44(3):241-3, 2011.

Liquidate, B. M.; Barros, M. D.; Alves, A. L. \& Pereira, C. S. B. Anatomical study of the digastric muscle: variations in the anterior belly. Int. J. Morphol., 25(4):797-800, 2007.

Mascaro, M. B.; Picoli, L. C.; Santos, F. M.; Bonsi, A. B.; de Souza, M. R. \& Prosdócimi, F. C. Anatomical variation of the anterior belly of the digastric muscle: case report and clinical implications. J. Morphol. Sci., 28(1):72-5, 2011. 
Moore, K. L.; Dalley, A. F. \& Agur, A. M. Clinically Oriented Anatomy. $7^{\text {th }}$ ed. Philadelphia, Lippincott Williams \& Wilkins, 2014.

Nayak, B. S.; Rao, S. S.; Sudarshan, S.; Prasad, A. M. \& Deepthinath, R. A morphological variant of anterior belly of digastric muscle: a cadaveric case report. Bangladesh J. Med. Sci., 16(3):461-3, 2017.

Ozgur, Z.; Govsa, F. \& Ozgur, T. The cause of the difference in the submental region: aberrant muscle bundles of the anterior belly of the digastric muscle. J. Craniofac. Surg., 18(4):875-81, 2007.

Quadros, L. S.; Saini, H.; Babu, A. \& Kiruba, L. Unilateral variant anterior belly of the digastric muscle. Int. J. Anat. Var., 6:101-2, 2013.

Raju, S.; Kanchana, L.; Venu, M. N.; Raghu Jetti \& Srinivasa, R. S. A rare bilateral asymmetric variation of the anterior belly of digastric muscle. J. Surg. Acad., 4(2):29-31, 2014.

Rani, A.; Chopra, J.; Rani, A. \& Verma, R. K. Duplicated anterior belly of the digastric muscle. Singapore Med. J., 54(6):e131-2, 2013.

Reyes, G.; Contreras, C.; Ramírez, L. M. \& Ballesteros, L. E. The digastric muscle's anterior accessory belly: Case report. Med. Oral Patol. Oral Cir. Bucal, 12:E341-3, 2007.

Turan-Ozdemir, S.; Oygucu, I. H. \& Kafa, I. M. Bilateral abnormal anterior bellies of digastric muscles. Anat. Sci. Int., 79(2):95-7, 2004.

Zdilla, M. J.; Pancake, A. R. \& Lambert, H. W. Morphometrics of the anterior belly and intermediate tendon of the digastric muscle: sexual dimorphism and implications for surgery. J. Craniofac. Surg., 27(5):1321-6, 2016.

Zhao, W.; Liu, J.; Xu, J. \& Wang, H. Duplicated posterior belly of digastric muscle and absence of omohyoid muscle: a case report and review of literature. Surg. Radiol. Anat., 37(5):547-50, 2015.
Corresponding author:

Professor K. S. Satyapal

School of Laboratory Medicine and Medical Science College of Health Sciences

Westville Campus University of KwaZulu-Natal

Private Bag X54001

Durban

4000

SOUTH AFRICA

Email: satyapalk@ukzn.ac.za

Received: 25-01-2019

Accepted: 02-07-2019 